\title{
Rational drug use for acute bronchiolitis in emergency care
}

\author{
Metin Uysalol ${ }^{1}$, Fatih Haşlak ${ }^{1}$, Zeynep Güneş Özünal ${ }^{2}$, Hayriye Vehid ${ }^{3}$, Nedret Uzel ${ }^{1}$ \\ ${ }^{1}$ Department of Pediatric Emergency, ${ }^{2}$ Department of Pharmacology, Istanbul University, Istanbul Faculty of Medicine; \\ ${ }^{3}$ Department of Biostatistics, Child Health Institute, Istanbul University, Istanbul, Turkey. \\ E-mail: uysalol@istanbul.edu.tr \\ Received: 26th December 2016, Revised: 6th April 2017, Accepted: 11th April 2017
}

SUMMARY: Uysalol M, Haşlak F, Özünal ZG, Vehid H, Uzel N. Rational drug use for acute bronchiolitis in emergency care. Turk J Pediatr 2017; 59: 155-161.

Despite the large variety of inhaled treatment options of acute bronchiolitis, there is no generally agreed treatment regime. This study aimed to determine the most appropriate treatment option. This was a double-blind randomized prospective clinical trial and has been performed in emergency department. The mean age of the 378 infants included in the study was $7.63 \pm 4.6$ months, and $54.8 \%$ (207) were boys. Patients were randomized by using the lottery method for simple random sample into 5 different treatment options; $3 \%$ hypertonic saline, nebulized adrenaline, nebulized adrenaline mixed with $3 \%$ hypertonic saline, nebulized salbutamol, and as control group; normal saline $(0.9 \% \mathrm{NaCl})$. From the first treatment time until discharge time; treatment durations, adverse events and readmission rates within the first fifteen days were recorded for each patient. Nebulized adrenaline mixed with $3 \%$ hypertonic saline, as compared with other options, were associated with a significantly higher discharge rate at $4^{\text {th }}$ hours $(\mathrm{p}<0.001)$ and shorter length of hospital stay $(p=0.039)$. However, there was no significant difference between options with regard to adverse events, discharge rates at $24^{\text {th }}$ hours, and readmission rates within the first fifteen days. The superiority of discharge rates at 4 hours of nebulized adrenaline mixed with $3 \%$ hypertonic saline, was evaluated as 'better acute response' and can be helpful to reduce hospitalization needs. Additionally, this option seems to be more effective to reduce length of hospital stay.

Key words: bronchiolitis, epinephrine, patient discharge, patient readmission, adverse effects.

Acute bronchiolitis is one of the most common causes of emergency room admissions in the first year of life.

Most infants with acute bronchiolitis (AB) have mild, self-limiting illness and recover completely ${ }^{1}$. Although it has a benign clinical course, bronchiolitis seems an important disease among infants and is the leading cause of hospitalization in infancy ${ }^{2}$. The hospitalization rate varies between $1 \%$ and $20 \%$ among children less than 24 months of age during seasonal epidemics ${ }^{3-5}$.

The American Academy of Pediatrics (AAP) recommendations do not support use of bronchodilators, corticosteroids, antibiotics, and diagnostic testing for patients with bronchiolitis ${ }^{6}$. There is great variation in the clinical management of $\mathrm{AB}^{7}$. The optimal pharmacological therapy in $A B$ is still controversial $^{8}$. The mainstay of therapy is supportive care such as adequate hydration, management of secretions, supplementary oxygen, and mechanical ventilatory support as needed ${ }^{9}$. In addition to supportive care, nebulized bronchodilators (salbutamol, adrenaline, ipratropium bromide) and corticosteroids are commonly used in clinical practice. Even if there is no exact evidence for administration of nebulized epinephrine to infants with a diagnosis of $\mathrm{AB}$; according to AAP guidelines, more studies are needed to consider for treatment of outpatients ${ }^{6}$. Multiple comparisons of symptomatic therapies in varying doses have been undertaken and outcomes have varied widely even within 
the same country ${ }^{10-14}$. There is no agreed therapeutic standard of care worldwide. The management of disease differs greatly also in our country, Turkey.

We had two aims in this study. The primary aim was to determine the most appropriate therapy for patients with $\mathrm{AB}$ in the emergency department that provides the earliest discharge, reduces length of hospital stay (LOS) hours, and cause less readmission rates (RR). The secondary aim was to determine if there were any significant adverse events (AE) during medication. We tested the hypothesis that there is no significant difference between inhaled treatment options with regard to LOS, discharge rates (DR), RR, and $A E$ in the treatment of $A B$ in infancy.

\section{Material and Methods}

\section{Patients and Study Design}

This was a randomized double-blind prospective study in the Pediatric ED of Istanbul University Istanbul Faculty of Medicine, between October 2011 and April 2012. The study protocol was approved by the Institutional Ethics Committee of Istanbul Faculty of Medicine The recommendations of the Declaration of Helsinki for biomedical research involving human subjects were followed. Children with $A B$ aged between 2-24 months with a score as moderate (4-8) in the bronchiolitis clinical score (BCS) system were included ${ }^{15}$. Infants who had symptoms of viral respiratory tract infections such as coryza, cough, fever, and clinical findings of bronchiolitis like tachypnea, respiratory distress with chest recession, wheezing and/or crackles were studied. Exclusion criteria were being younger than 2 months old, prematurity (less than $36^{\text {th }}$ gestational week), low birth weight (less than 2,500 g), history of admission in neonatal intensive care unit due to respiratory distress, history of intubation in the intensive care unit, congenital heart/lung/neurologic or immunologic disease, history of atopic disease or recurrent wheezing, clinical or radiologic findings of bacterial infections, atelectasis or consolidations on X-ray and refusal to consent by parents.

Based on mean and standard deviation values of LOS in a previous study of Tal et al. ${ }^{16}$, a power analysis revealed that, for detection of

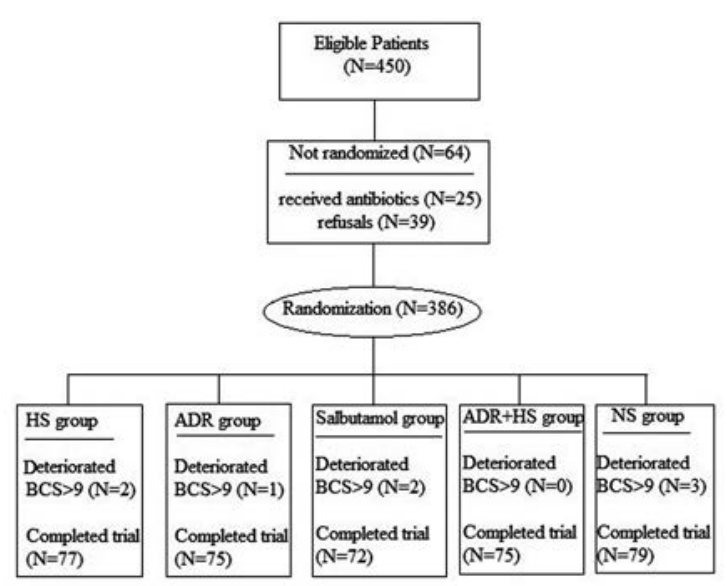

Fig. 1. Selection and randomization of patients

this significant LOS difference between the five treatment groups, with an $\alpha$ of 0.05 , power of $90 \%$ and standardized effect size of 0.55 , we required at least 350 patients (70 per group). The study was not powered to detect differences in secondary outcome measures.

Informed consents were obtained from parents of children included in the study. The patients were evaluated according to the inclusion and exclusion criteria. The patients enrolled in the study were randomized by using the lottery method for simple random sample into treatment options (Fig. 1).

The first 4 hours of the study passed in the observation unit (OU). At the end of 4 hours, the patient's discharge status was decided. Nonresponders were admitted to the emergency observation unit (EOU). Discharge status was evaluated after 24 hours. Patients who were not discharged received continued treatment in the pediatric emergency service (PES).

\section{Data Collection}

Clinical data and demographic information were collected by the same pediatrician. The patients were divided into five treatment groups: $3 \%$ hypertonic saline (HS), nebulized adrenaline (ADR), nebulized adrenaline mixed with $3 \%$ hypertonic saline (ADR $+\mathrm{HS}$ ), nebulized salbutamol and as control group normal saline $(0.9 \% \mathrm{NaCl})(\mathrm{NS})$ among children presenting to the Emergency Department (ED) with AB. Infants were examined at 0-240 minutes for respiratory rate, pulse, $\mathrm{SaO}_{2}, \mathrm{AE}$, and $\mathrm{BCS}$ were recorded in the case report form. Infants were evaluated using BCS at 4-hour intervals 
Table I. Demographic and Clinical Characteristics of the Patients at Admission According to Treatment Groups.

\begin{tabular}{|c|c|c|c|c|c|c|}
\hline \multirow[b]{2}{*}{ Characteristics } & \multicolumn{5}{|c|}{ Treatment Groups } & \multirow[b]{2}{*}{$\mathrm{P}$} \\
\hline & $\begin{array}{l}\text { HS } \\
(\mathrm{n}: 77)\end{array}$ & $\begin{array}{l}\text { ADR } \\
(\mathrm{n}: 75)\end{array}$ & $\begin{array}{l}\text { Salbutamol } \\
\text { (n: } 72)\end{array}$ & $\begin{array}{l}\text { ADR+HS } \\
(\mathrm{n}: 75)\end{array}$ & $\begin{array}{l}\text { Normal } \\
\text { saline } \\
\text { (n: 79) }\end{array}$ & \\
\hline Age (month)* & $7(4-10)$ & $7(4-10)$ & $7(4-10)$ & $7(4-10)$ & $7(4-10)$ & 1.00 \\
\hline Weight $(\mathrm{kg})^{*}$ & $8.5(7-10)$ & $8.2(7-10)$ & $8.25(7-11)$ & $8.2(\ldots)$ & $8.3(7-10)$ & 0.99 \\
\hline Male/Female $(\% / \%)$ & $55.8 / 44.2$ & $54.7 / 45.3$ & $54.2 / 45.8$ & $54.7 / 45.3$ & $54.4 / 45.6$ & 1.00 \\
\hline Temperature $\left({ }^{\circ} \mathrm{C}\right)^{*}$ & $\begin{array}{l}37.5 \\
(36.4-38.2)\end{array}$ & $\begin{array}{l}37.5 \\
(36.4-38.2)\end{array}$ & $\begin{array}{l}37.65 \\
(37.5-38.2)\end{array}$ & $\begin{array}{l}37.5 \\
(36.4-38.2)\end{array}$ & $\begin{array}{l}37.5 \\
(36.3-38.1)\end{array}$ & 0.763 \\
\hline $\begin{array}{l}\text { Duration of URTI } \\
\text { symptoms (days)* }\end{array}$ & $5(4-5)$ & $5(4-5)$ & $5(4-5)$ & $5(4-5)$ & $5(4-5)$ & 0.964 \\
\hline $\begin{array}{l}\text { Duration of wheezing } \\
\text { (days)* }\end{array}$ & $2(2-3)$ & $2(1-3)$ & $2(2-3)$ & $2(1-3)$ & $2(2-3)$ & 0.935 \\
\hline
\end{tabular}

*Data is presented as median $\left(25^{\text {th }}-75^{\text {th }}\right.$ percentile)

HS: 3\% hypertonic saline; ADR: nebulized adrenaline; ADR+HS: nebulized adrenaline mixed with $3 \%$ hypertonic saline.

and a score less than 3 were considered for discharge decision.

Length of hospital stay hours were considered between first treatment and discharge time. Adverse events (tachycardia, pallor, tremor, nausea, vomiting) were recorded within the LOS. Readmission to the hospital within first 15 days was recorded. The primary outcomes of the study were DR and LOS, and the secondary outcomes were RR and AE to evaluate efficacy and safety of the treatment.

Infants aged younger than 2 months $(n=13)$, with low birth weight $(n=7)$, and those born before the 36th gestational week $(n=9)$ were excluded before randomization. 450 patients were eligible for the study. However, 25 patients had bacterial infection findings and received antibiotics and informed consents were refused by parents of 39 patients. Therefore 386 patients were randomized. During the study, infants whose BCS have deteriorated worse than 9 were excluded from the study ( 2 in HS group, 1 in ADR group, 2 in salbutamol group and 3 in NS group). At the end, 378 patients were able to complete the trial (Fig. 1).

\section{Treatments}

Drugs were administered by means of standard hospital nebulizers through a firmly applied face mask with an oxygen flow of 6 liters per minute within 6-8 minutes. Group HS was given $4 \mathrm{ml} \mathrm{HS}$, group ADR received $4 \mathrm{ml} \mathrm{NS}$ with ADR $0.1 \mathrm{mg} / \mathrm{kg}$, group Salbutamol had nebulized salbutamol $0.15 \mathrm{mg} / \mathrm{kg}$ with $4 \mathrm{ml}$ $\mathrm{NS}$, group ADR + HS received $4 \mathrm{ml} \mathrm{HS}$ with $0.1 \mathrm{mg} / \mathrm{kg} /$ dose ADR, and as control group; group NS was administered $5 \mathrm{ml} \mathrm{NS}$ at 0,30 , and 60 minutes, and every 4 hours thereafter if needed to a maximum of $24 \mathrm{~h}$ (Fig. 1).

\section{Statistical Analysis}

The statistical analysis was performed using SPSS for Windows, version 16.0 (SPSS Inc., Chicago, IL). One-way analysis of variance (ANOVA) was used to measure the distribution of demographic and clinical variables such as age, weight, temperature, duration of URTI and duration of wheezing. Because of gender is a dichotomous event, Pearson chi-square test was performed to measure distribution among infants. Pearson chi-square test was performed also for evaluating of outcomes of the study such as DR at 4 hours, DR at 24 hours, RR and AE. LOS is not a dichotomy event; it is intermittent variable. Thus, to evaluate LOS; ANOVA was used. To detect the cause of significant difference; in DR at 4 hours, binary logistic regression test was performed and in LOS, as post hoc method, Tukey analysis was performed. Statistical significance was defined as $\mathrm{p}<0.05$.

\section{Results}

The study included 378 patients with a mean 
Table II. Outcome Measures of the Study According to Treatment Groups

\begin{tabular}{|c|c|c|c|c|c|c|c|}
\hline \multirow[t]{2}{*}{ Outcomes } & \multicolumn{6}{|c|}{ Treatment Groups } & \multirow[t]{2}{*}{$\mathrm{p}$} \\
\hline & $\begin{array}{l}\text { HS } \\
(\mathrm{n}: \\
77)\end{array}$ & $\begin{array}{l}\text { ADR } \\
\text { (n: } \\
75)\end{array}$ & $\begin{array}{l}\text { Salbutamol } \\
\text { (n: } 72)\end{array}$ & $\begin{array}{l}\text { ADR+HS } \\
\text { (n: } 75)\end{array}$ & $\begin{array}{l}\text { Normal } \\
\text { saline } \\
\text { (n: } 79)\end{array}$ & $\begin{array}{l}\text { Total } \\
\text { (n: 378) }\end{array}$ & \\
\hline $\begin{array}{l}\text { Discharge rate at } 4 \mathrm{hrs}, \mathrm{n} \\
(\%)\end{array}$ & $\begin{array}{l}37 / 77 \\
(48.1)\end{array}$ & $\begin{array}{l}42 / 75 \\
(56.0)\end{array}$ & $\begin{array}{l}27 / 72 \\
(37.5)\end{array}$ & $\begin{array}{l}52 / 75 \\
(69.3)\end{array}$ & $\begin{array}{l}29 / 79 \\
(36.7)\end{array}$ & $\begin{array}{l}187 / 378 \\
(49.5)\end{array}$ & 0.001 \\
\hline $\begin{array}{l}\text { Discharge rate at } 24 \mathrm{hrs}, \\
\mathrm{n}(\%)\end{array}$ & $\begin{array}{l}69 / 77 \\
(89.6)\end{array}$ & $\begin{array}{l}66 / 75 \\
(88.0)\end{array}$ & $\begin{array}{l}63 / 72 \\
(87.5)\end{array}$ & $\begin{array}{l}71 / 75 \\
(94.7)\end{array}$ & $\begin{array}{l}66 / 79 \\
(83.5)\end{array}$ & $\begin{array}{l}335 / 378 \\
(88.6)\end{array}$ & 0.294 \\
\hline $\begin{array}{l}\text { Readmission rate within } \\
\text { first } 15 \text { days, } \mathrm{n}(\%)\end{array}$ & $\begin{array}{l}14 / 77 \\
(18.2)\end{array}$ & $\begin{array}{l}14 / 75 \\
(18.7)\end{array}$ & $\begin{array}{l}19 / 72 \\
(26.4)\end{array}$ & $\begin{array}{l}14 / 75 \\
(18.7)\end{array}$ & $\begin{array}{l}20 / 79 \\
(25.3)\end{array}$ & $\begin{array}{l}81 / 378 \\
(21.4)\end{array}$ & 0.571 \\
\hline $\begin{array}{l}\text { Adverse events } \\
\text { (tachycardia, pallor, tremor, } \\
\text { nausea, vomiting), n (\%) }\end{array}$ & $\begin{array}{l}0 \\
(0)\end{array}$ & $\begin{array}{l}7 / 75 \\
(9.3)\end{array}$ & $\begin{array}{l}7 / 72 \\
(9.7)\end{array}$ & $\begin{array}{l}5 / 75 \\
(6.7)\end{array}$ & $\begin{array}{l}2 / 79 \\
(2.5)\end{array}$ & $\begin{array}{l}21 / 378 \\
(5.6)\end{array}$ & 0.079 \\
\hline $\begin{array}{l}\text { Length of stay (hours), } \\
\text { median (IQR) }\end{array}$ & $8(12)$ & $4(12)$ & $16(20)$ & $4(8)$ & $16(20)$ & $10(16)$ & 0.039 \\
\hline
\end{tabular}

HS: 3\% hypertonic saline; ADR: nebulized adrenaline; ADR+HS: nebulized adrenaline mixed with 3\% hypertonic saline.

age of $7.63 \pm 4.6$ months. Male sex ratio was $54.8 \%$ within the study population. There were no significant differences between treatment groups in terms of age, sex, clinical parameters (weight, body temperature, duration of upper respiratory tract infection (URTI) symptoms and duration of wheezing at admission to hospital (Table I).

\section{Discharge Rates}

Discharge rates (DR) of treatment options were compared at $4^{\text {th }}$ and $24^{\text {th }}$ hours. At the end of 4 hours, 187 patients (49.5\%) were discharged and DR at $4^{\text {th }}$ hour were found statistically significant $(p<0.001)$. ADR + HS treatment option had the highest DR at $4^{\text {th }}$ hour with $69.3 \%$ (Table II). To Compare DR at $4^{\text {th }}$ hour of treatment options, NS group was defined as control group and binary logistic regression test was performed; in ADR group $(\mathrm{p}=0.017)$ and in ADR +HS group $(\mathrm{p}<0.001)$ discharge rates at $4^{\text {th }}$ hour were significantly higher (Table III). At the end of 24 hours, 335 of 378 patients were discharged (88.6\%). Within the treatment options there was no statistically significant difference in terms of DR at $24^{\text {th }}$ hour (Table II).

\section{Length of Hospital Stay}

Length of hospital stay was statistically different between the treatment options $(p=$ 0.039). ADR + HS group had the shortest
LOS values with a median of 4 hours (IQR: 8) (Table II). To compare LOS of treatment options, NS group was defined as control group Kruskal-Wallis analysis was performed and adjusted for treatment group numbers $(p<0.01$; paired group analysis is performed with Mann Whitney. In ADR + HS group LOS were significantly lower $(\mathrm{p}<0.001)$.

\section{Readmission Rates}

Readmission rates between treatment options within the first 15 days were evaluated and were not different $(\mathrm{p}=0.571)$ (Table II).

\section{Adverse Events}

As adverse events; tachycardia, pallor, tremor, nausea and vomiting were observed within the LOS. The total frequency was $5.5 \%$ and the frequencies were not different when compared between treatment options $(\mathrm{p}=0.079)$ (Table II).

\section{Discussion}

The short-term benefits in clinical response are more valuable to physicians in pediatric ED. Managing patient circulation with outpatient treatments and reducing the need for hospitalization especially comes into prominence in crowded cities such as Istanbul. For our ED, the EOU includes many types of patients. Therefore, discharging patients from the OU provides us enough logistic facilities 
for hospitalization and prevents close patientto-patient interactions, which reduces the risk of contagion.

To evaluate the short-term clinical benefits, outcomes of patients who were discharged before 24 hours were considered. Additionally, to evaluate acute response differences, outcomes of patients who were discharged within the first 4 hours were considered. Our other primary outcome has shown that clinical benefits in acute response provided with ADR + HS and/ or ADR treatment was significantly superior to the other treatment options. This statistical data may be helpful to reduce hospitalization rates in infants with $A B$. In the study of Grewal et al. ${ }^{17}$; clinical score from baseline to 120 minutes demonstrated no improvement in respiratory distress in $\mathrm{ADR}+\mathrm{HS}$ group compared with ADR group. A study from Iran demonstrated that ADR treatment provides better recovery in infants with $\mathrm{AB}$ compared to nebulized salbutamol ${ }^{18}$. In the study of Sanchez et al. ${ }^{19}$, clinical score and pulmonary mechanics of patients were evaluated just 30 minutes after the initial treatment and ADR was found superior to nebulized salbutamol. In a study from India, nebulized salbutamol and L-epinephrine were compared with regard to clinical responses in first three hours and significantly more children in ADR group could be sent home after the emergency treatment ${ }^{20}$.

For measuring the efficacies, LOS hours were also used. The mean LOS was significantly shorter for children in the group receiving ADR + HS than in the groups receiving treatment HS, NS, nebulized salbutamol or ADR. According to a review prepared by Chen et al. ${ }^{21}$; HS significantly decreased both the rate and the duration of hospitalization. A study from Spain has demonstrated that ADR+HS significantly shortens LOS in hospitalized infants with acute moderate bronchiolitis compared to $\mathrm{HS}^{22}$. In the study of Miraglia et al. ${ }^{23}$; ADR + HS was found significantly superior to ADR with regard to LOS. The superiority of ADR + HS over ADR and HS may be a consequence of a synergistic or additive effect.

In infants with $A B$ there was no statistically significant difference for long-term efficacy between the treatment options. To consider this, RR within first fifteen days were evaluated and we found that no treatment was superior to another $(p=0.571)$. Similar to ours; in the study of Anil et al. ${ }^{24}$; NS, HS, ADR and nebulized salbutamol options were compared and no significant difference was found with regard to RR.

As much as efficacy, drug safety is also important for rational use. To evaluate drug safety, we considered AE. For our secondary outcome, the frequency of $\mathrm{AE}$ in our study groups was within acceptable limits, none was clinically significant and there were no statistically significant differences between treatment options $(p=0.079)$. Furthermore, the detected AE may have been reflexes not true symptoms, a natural infantile agitated behavior response to any intervention. In a study from Israel, $\mathrm{AE}$ and benefits on clinical response of ADR+HS were observed and no AE were detected $^{25}$. Another double-blind trial with 46 patients who received ADR $+\mathrm{HS}$ reported $\mathrm{AE}$ in four patients ${ }^{17}$ (vomiting in 3 patients, diarrhea in 1 patient).

The number of patients assessed eligibility was decreased because we excluded infants aged younger than 2 months (13 infants), with low birth weight (7 infants), and those born before

Table III. Comparison of Discharge Rates at 4 Hours of Treatment Options (Reference Group: Normal saline)

\begin{tabular}{|c|c|c|c|c|}
\hline \multirow[b]{2}{*}{ Treatment options } & \multirow[b]{2}{*}{ Odds ratio } & \multicolumn{2}{|c|}{ Confidence interval \%95 } & \multirow[b]{2}{*}{$\mathrm{P}$ value } \\
\hline & & Lower & Upper & \\
\hline Hypertonic saline & 1.595 & 0.841 & 3.024 & 0.153 \\
\hline Adrenaline & 2.194 & 1.150 & 4.186 & 0.017 \\
\hline Salbutamol & 1.034 & 0.534 & 2.004 & 0.920 \\
\hline $\begin{array}{l}\text { Adrenaline mixed } \\
\text { hypertonic saline }\end{array}$ & 3.898 & 1.993 & 7.625 & $<0.001$ \\
\hline
\end{tabular}


the 36 th gestational week (9 infants) before randomization. Many studies have shown that LOS is longer and these infants are more likely to be admitted to the intensive care unit with severe disease ${ }^{26-27}$. Therefore, including such infants is considered to be harmful for the homogeneity of study patients. Furthermore, although not previously shown, the possibility that NS may have a bronchoconstrictive effect in infants (aged younger than 2 months) should not be ignored ${ }^{26}$. In order to be able to observe clinical recovery in patients faithfully, similar to the study of Jacob et al. ${ }^{28}$; ones had mild symptoms (1-3 score in BCS) were not included. Additionally, ones had severe symptoms (9-12 score in BCS) may be resistant to inhaled treatment regimes, may require more aggressive supportive care and all these disadvantages may prevent to get reliable results. Therefore, similar to the study of Grewal et $\mathrm{al}^{17}$, they were also not included in the study.

A randomized double-blind trial from Norway showed that LOS was significantly shorter for children in the on-demand treatment group than in the group that received treatment on a fixed schedule ${ }^{26}$. While considering the clinical responses in our study groups, the use of a fixed schedule may have decreased the clinical recovery in all patients. However, it seems to have had no effect on recovery. Even if the recovery was affected, there was no significant difference in hospitalization between the fixed schedule and on-demand schedule comparisons in the Norwegian study ${ }^{26}$. Thus, our clinically and statistically significant 'acute response' (4 hours) data may not have been affected by the fixed schedule option. However, a study that includes a five by two factorial design may be needed in the future.

This study showed that for the treatment of infants with $A B, A D R+H S$ is superior to other inhaled treatment options (HS, NS, ADR and salbutamol) with regard to LOS and DR in the first 4 hours. Reduced LOS and increased DR are important outcomes for emergency care settings when limited capacity and other risk factors are considered. Furthermore, rates and severity of $\mathrm{AE}$ with $\mathrm{ADR}+\mathrm{HS}$ were similar to the other treatments and there was no statistically significant difference between them. However, this combination treatment was not associated with a lower RR. Although it has been evaluated for considering long-term efficacy, longer observation periods will be necessary in the future.

\section{REFERENCES}

1. Simsek-Kiper PO, Kiper N, Hascelik G, et al. Emergency room management of acute bronchiolitis: a randomized trial of nebulized epinephrine. Turk J Pediatr 2011; 53: 651-660.

2. Leader S, Kohlhase K. Recent trends in severe respiratory syncytial virus (RSV) among US infants, 1997 to 2000. J Pediatr 2003; 143: 127-132.

3. Simoes EF. Environmental and demographic risk factors for respiratory syncytial virus lower respiratory tract disease. J Pediatr 2003; 143: 118-126.

4. Hall BC, Long CE, Schnabel KC. Respiratory syncytial virus infections in previously healthy working adults. Clin Infect Dis 2001; 33: 792-796.

5. Yorita KL, Holman RC, Sejvar JJ, Steiner CA, Schonberger LB. Infectious disease hospitalizations among infants in the United States. Pediatrics 2008; 121: 244-252.

6. Ralston SL, Lieberthal AS, Meissner HC, et al. Clinical practice guideline: the diagnosis, management, and prevention of bronchiolitis. Pediatrics 2014; 134: 14741502.

7. Seiden JA, Scarfone RJ. Bronchiolitis: An evidencebased approach to management. Clin Pediatr Emerg Med 2009; 10: 75-81.

8. Kuyucu S, Unal S, Kuyucu N, Yilgor E. Additive effects of dexamethasone in nebulized salbutamol or L-epinephrine treated infants with acute bronchiolitis. Pediatr Int 2004; 46: 539-544.

9. Wright RB, Pomerantz WJ, Luria JW. New approaches to respiratory infections in children: bronchiolitis and croup. Emerg Med Clin North Am 2002; 20: 93-114.

10. Wainwright $\mathrm{C}$, Altamirano L, Cheney $\mathrm{M}$, et al. A multicenter, randomized, double-blind, controlled trial of nebulized epinephrine in infants with acute bronchiolitis. N Engl J Med 2003; 349: 27-35.

11. Mull CC, Scarfone RJ, Ferri LR, et al. A randomized trial of nebulized epinephrine vs albuterol in the emergency department treatment of bronchiolitis. Arch Pediatr Adolesc Med 2004; 158: 113-118.

12. Scarfone R. Controversies in the treatment of bronchiolitis. Curr Opin Pediatr 2005; 17:62-66.

13. Smyth RL, Openshaw PJ. Bronchiolitis. Lancet 2006; 368: 312-322.

14. Bush A, Thomson AH. Acute bronchiolitis. BMJ 2007; 335: 1037-1041.

15. Wang EE, Milner RA, Navas L, Maj H. Observer agreement for respiratory signs and oxymetry in infants hospitalized with lower respiratory infections. Am Rev Respir Dis 1992; 145: 106-109. 
16. Tal G, Cesar K, Oron A, Houri S, Ballin A, Mandelber A. Hypertonic saline/epinephrine treatment in hospitalized infants with viral bronchiolitis reduces hospitalization stay: 2 years' experience. Isr Med Assoc J 2006; 8: 169-173.

17. Grewal S, Ali S, McConnell DW, Vandermeer B, Klassen TP. A randomized trial of nebulized $3 \%$ hypertonic saline with epinephrine in the treatment of acute bronchiolitis in the emergency department. Arch Pediatr Adolesc Med 2009; 163: 1007-1012.

18. Modaressi MR, Asadian A, Faghihinia J, Arashpour M, Mousavinasab F. Comparison of epinephrine to salbutamol in acute bronchiolitis. Iran J Pediatr 2012; 22 : 241-244.

19. Sanchez I, De Koster J, Powell RE, Wolstein R, Chernick $\mathrm{V}$. Effect of racemic epinephrine and salbutamol on clinical score and pulmonary mechanics in infants with bronchiolitis. J Pediatr 1993; 122: 145-151.

20. Ray MS, Singh V. Comparison of nebulized adrenaline versus salbutamol in wheeze associated respiratory tract infection in infants. Indian Pediatr 2002; 39: 12-22.

21. Chen YJ, Lee WL, Wang CM, Chou HH. Nebulized hypertonic saline treatment reduces both rate and duration of hospitalization for acute bronchiolitis in infants: an updated meta-analysis. Pediatrics \& Neonatology 2014; 55: 431-438.
22. Flores-González JC, Matamala-Morillo MA, RodriguezCampoy P, et al. Epinephrine improves the efficacy of nebulized hypertonic saline in moderate bronchiolitis: a randomised clinical trial. PloS One 2015; 10: e0142847.

23. Miraglia MDG, Saitta F, Leonardi S, et al. Effectiveness of nebulized hypertonic saline and epinephrine in hospitalized infants with bronchiolitis. Int J Immunopathol Pharmacol 2012; 25: 485-491.

24. Anil AB, Anil M, Saglam AB, Cetin N, Bal A, Aksu $N$. High volume normal saline alone is as effective as nebulized salbutamol-normal saline, epinephrinenormal saline, and 3\% saline in mild bronchiolitis Pediatr Pulmonol 2010; 45: 41-47.

25. Mandelberg A, Tal G, Witzling M, et al. Nebulized 3\% Hypertonic Saline Solution Treatment in Hospitalized Infants With Viral Bronchiolitis. Chest 2003; 123: 481-487.

26. Skjerven HO, Hunderi JO, Brügmann-Pieper SK, et al Racemic adrenaline and inhalation strategies in acute bronchiolitis. N Engl J Med 2013; 368: 2286-2293.

27. Sala KA, Moore A, Desai S, Welch K, Bhandari S, Carroll CL. Factors associated with disease severity in children with bronchiolitis. J Asthma 2015; 52: 268-272.

28. Jacobs JD, Foster M, Wan J, Pershad J. 7\% Hypertonic saline in acute bronchiolitis: a randomized controlled trial. Pediatrics 2014; 133: e8-e13. 